\title{
Assessment of Groundwater Resource in Climate Variability Context at Sinematiali (North of Côte d'Ivoire)
}

\author{
Omer Zephir De Lasme, Avy Stephane Koffi, and Dodo Guy Cedric Gnali
}

\section{ABSTRACT}

\begin{abstract}
Study of climate variability gets great importance for integrated water resources management. This work examines impact of climate variability on the evolution of water resources in the Bandama sub-watershed at Sinematiali with a view of better management. The time series of rainfall and discharge were used as a database for this purpose. Known calculation hydrologic methods of Nicholson, Maillet as well as the statistical test for breaking detection (Pettitt test) were applied. The effective rain and recharge were estimated by using the ESPERE software models over the period 1980 to 1987 . Climate variability is characterized by alternative season of wet, normal, and dry periods, and a pluviometry break occurred in 1984 year. The annual effective rain was assessed from 30 to $570 \mathrm{~mm}$ while recharge of aquifers estimated between 2 and $333 \mathrm{~mm}$. This work constitutes a fundamental base for modeling water resources management at Sinematiali.
\end{abstract}

Keywords: climate variability, sub-watershed, rainfall, runoff, recharge, Sinematiali.

\section{INTRODUCTION}

Many concerns about water resources involve questions about their future sustainability due to growth of its demand by people in urban and rural areas. Viewing ground water is not a nonrenewable resource, such as a mineral or petroleum deposit, it seems like any quantitative improvement was experienced while rainfall remains the main source of surface and ground waters. However, a prolonged dry period when maximum recharge normally

occurs can lower ground-water levels to the point at which shallow wells go dry [1]. Therefore, the survey of water resources is necessary for getting sustainable development for human being societies. [2] reported that $46 \%$ of cultivated areas in the world are not suitable for rained agriculture because of climate changes and other meteorological conditions. Then, increasing irrigated agriculture is necessary but not always economical everywhere. The lack of water available for agriculture practice is one of main reason of food shortages in many parts of the world such as less developed countries. Côte d'Ivoire, likely many sub-Sahara countries, has its economy based on rainfed agriculture. This study aims to provide water resources characteristics for getting integrated sustainable water resources management at Sinematiali area in sub-watershed of Bandama river. Specific
Published Online: October 13, 2020

ISSN: $2684-446 \mathrm{X}$

DOI 10.24018 / ejgeo.2020.1.5.73

Omer Zephir De Lasme*

Geosciences Department, Biological Sciences Faculty, University Peleforo Gon Coulibaly, Korhogo, Côte d'Ivoire. (e-mail: drdelasme@gmail.com)

\section{Avy Stephane Koffi}

Geosciences Department, Biological Sciences Faculty, University Peleforo Gon Coulibaly, Korhogo, Côte d'Ivoire.

(e-mail: koffistephane_1@yahoo.fr)

Dodo Guy Cedric Gnali

Geosciences Department, Biological Sciences Faculty, University Peleforo Gon Coulibaly, Korhogo, Côte d'Ivoire.

(e-mail: gnalidodoguycedric@gmail.com)

*Corresponding Author purposes of this study involved to:

- Determine the climate variability occurred in study area.

- Quantify groundwater resources stored in aquifers.

-Identify impacts of climate variability on water resources.

\section{PRESENTATION OF STUDY AREA AND CONTEXT}

\section{A. Localization}

The study area is localized in West Africa, at northern Côte d'Ivoire (Fig. 1). It is part of Bandaman River watershed that established between region of Ferkessédougou and Korhogo named Sinématiali. The Bandaman watershed at Sinématiali exactly is defined by meridians $5^{\circ} 15^{\prime}$ and $6^{\circ} 15^{\prime}$ west longitude on the one hand, $9^{\circ} 20$ 'and $10^{\circ} 20^{\prime}$ north latitude on the other hand. On hydrological view, this studied area is characterized by following parameters: $\mathrm{Kc}=1.14$; Long $=96$ $\mathrm{km}$ and large $=73 \mathrm{~km}$; Slope index $=0.043$. 


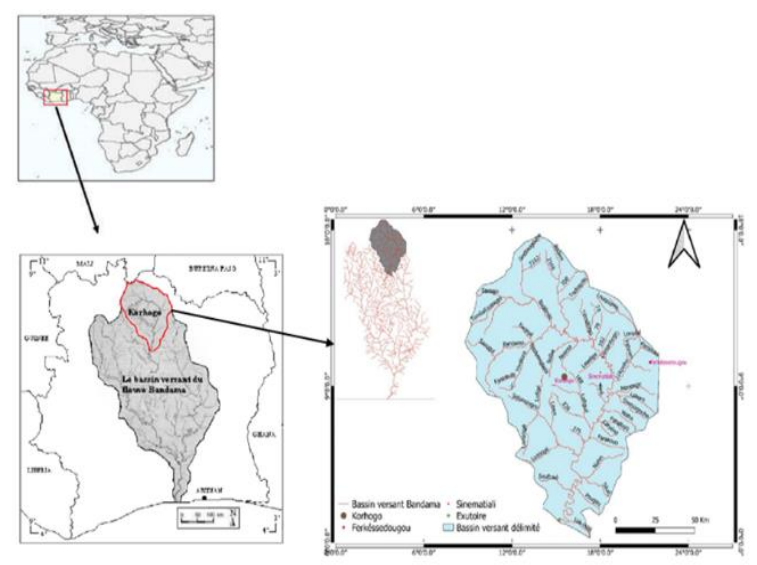

Fig. 1. Localization of studied area.

\section{B. Context}

Bandama River catchment is one of major hydrological Basin which is spreading from north to South of the country by providing surface water resource to many regions. By the way, many authors [3]-[5] worked on various aspects of this large basin. Some of them established physical parameters and land using while those focused on modelling and hydrological impacts of climate change. Most of them presented hydrodynamical overview and predictive scenarios of water resources, but none or little of them focused integrating water resources management at sub-watershed scale.

\section{MATERIALS AND METHODS}

\section{A. Material}

Database required for this study achievement are various. Hydroclimatic data relate to rainfall $(\mathrm{mm})$ and temperature $\left({ }^{\circ} \mathrm{C}\right)$ were necessary for identifying climate variability occurrence. Also, yields of flowing river were used to identify availability of surface water and to calculate quantity infiltrated water under the ground and part available for users through extraction with pumps.

Due to lack of hydroclimatic data collector station at Sinematiali, rainfalls and temperature data were collected at Ferkessedougou and Korhogo stations located respectively at $20 \mathrm{~km}$ and $35 \mathrm{~km}$ away of Sinematiali.

The hydrometric data collected from Bandama river's streams in Sinematiali's area were daily measurements of surface water at outlet of the catchment. These data covered the same period, from 1976 to 1996. For data processing, we used the following specialized worksheets:

- Microsoft Excel worksheet designed by [6] to calculate automatically potential evaporation and transpiration through Thornthwaite method well known in hydrological literature [7];

- The software ESPERE version 1.52 is Microsoft Excel spreadsheet designed by French Geological Survey to estimate effective rainfall and aquifer recharge through simultaneous calculations with up to ten different methods [8].

\section{B. Methods}

Climate variability was characterized by calculation of rainfall index through Nicholson formula below [9]:

$$
I \mathrm{p}=\frac{\mathrm{Xi}-\overline{\mathrm{X}}}{\delta}
$$

where:

IP: Rainfall index.

$X i$ : Rainfall (or discharge) for a year $i$.

$\overline{X:}$ Average annual rainfall (or flow) during a given period.

$\delta$ : Standard deviation of rainfall (or flow) over the given period.

Values of rainfall index allow to determine exactly duration of wet and dry hydrological seasons occurred in study area. In addition to determine a great climate rupture, it was also applying a non-parametric approach with following stationary equations called "Pettit test" [10]:

$$
U_{t, n}=\sum_{i=1}^{t} \sum_{J=t+1}^{N} D_{i j} \text { for } 1 \leq \mathrm{t} \leq \mathrm{n}
$$

where $D_{i j}=\operatorname{sgn}\left(X_{i}-X_{j}\right)$ and $X_{i}$ is the sorted data vector by date and the $s g n$ function is defined by: $\operatorname{sgn}(X)=1$ when $X>0 ; \operatorname{sgn}(X)=0$ when $X=0$ and $\operatorname{sgn}(X)=-1$ when $X<0$.

For getting rivers drying up duration, it was applied Maillet's equation below [11]:

$$
Q_{t=Q_{0}} e^{-k t}
$$

where $Q_{t}$ and $Q_{0}$ are the flows at respectively times $t$ and $t_{0}$ (start of the drying up) expressed in days, and $k$ is the Maillet drying-up coefficient depending on the physical and geometric characteristics of watershed considered.

Finally, recharge of aquifer and effective rainfall were estimated by using ESPERE software version 1.52. This Microsoft Excel worksheet application allows to apply several commonly used methods to estimate groundwater recharge rapidly and simultaneously. According to the available data at Sinematiali, we applied and compared the results of one empirical method (Turc), one slightly water budget method (Thornthwaite), and three hydrograph separation algorithms (Wallingford, Chapman and Eckhardt) Assessment of waters resources has lean to establish relationship between rainfalls, surface water and groundwater evolution in the common climate period.

\section{RESUlts}

\section{A. Climate variability}

Common database period for temperature, rainfall and rivers stream discharges is established from 1980 to 1987 with statistical values resumed in table 1 below:

Spreading of Nicholson index on whole period of rainfall database (1928-1987) indicated that great region of studied area experienced an unprecedented rainfall variability with two main climate periods: a long humid period from 1928 to 1970 and a short dry period from 1971 to 1987 according interannual rainfall average (see Fig. 2). 
TABLE I: STATISTICAL VALUES OF CLIMATE VARIABILITY DATABASE

\begin{tabular}{ccccc}
\multicolumn{4}{c}{ TABLE I: STATISTICAL VALUES OF CLIMATE VARIABILITY DATABASE } \\
\hline & Minimum & Maximum & Average & $\begin{array}{r}\text { Standard } \\
\text { deviation }\end{array}$ \\
\hline Rainfall (mm) & 881,4 & 1378,6 & 1117,77 & 138,48 \\
\hline $\begin{array}{c}\text { Temperature } \\
\left({ }^{\circ} \mathbf{C}\right)\end{array}$ & 26,2 & 27,65 & 26,73 & 0,45 \\
\hline $\begin{array}{c}\text { Discharge } \\
\left(\mathbf{m}^{\mathbf{3}} / \mathbf{s}\right)\end{array}$ & 721,9 & 16766 & 7864,82 & 5397,74 \\
\hline
\end{tabular}

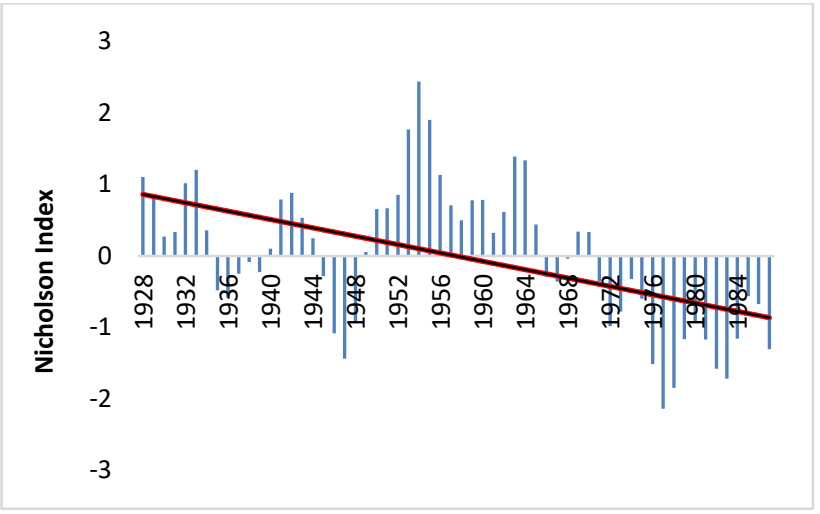

Fig. 2. Spreading of Nicholson Index for rainfall in the region.

Test of Pettit of stream rivers discharges highlighted year 1984 as an exact date of break in evolution of discharges at watershed (see Fig. 3).

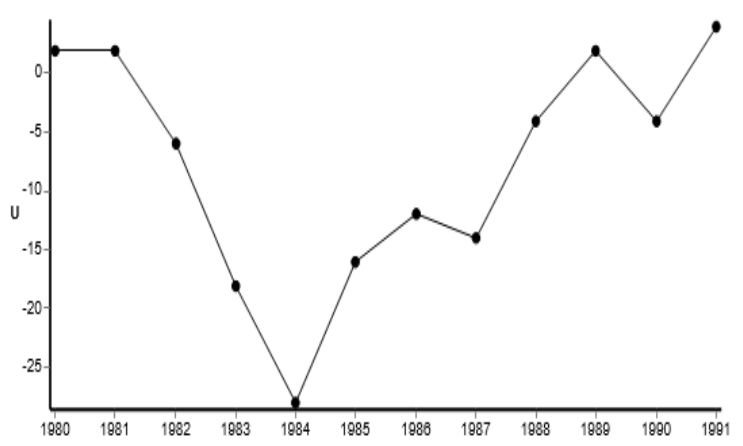

Fig. 3. Spreading of Pettit Test on stream rivers discharges.

\section{B. Effective rain and aquifer recharge estimated}

By using temperature and rainfalls data under ESPERE model conditions, only Turc and Thornthwaite methods allowed estimation of annual effective rain for eight years simulations (see Fig. 4). According this modeling solutions, effective rain evolved from 28 to $263 \mathrm{~mm}$ and from 195 to $555 \mathrm{~mm}$ respectively based on Thornthwaite and Turc methods findings:

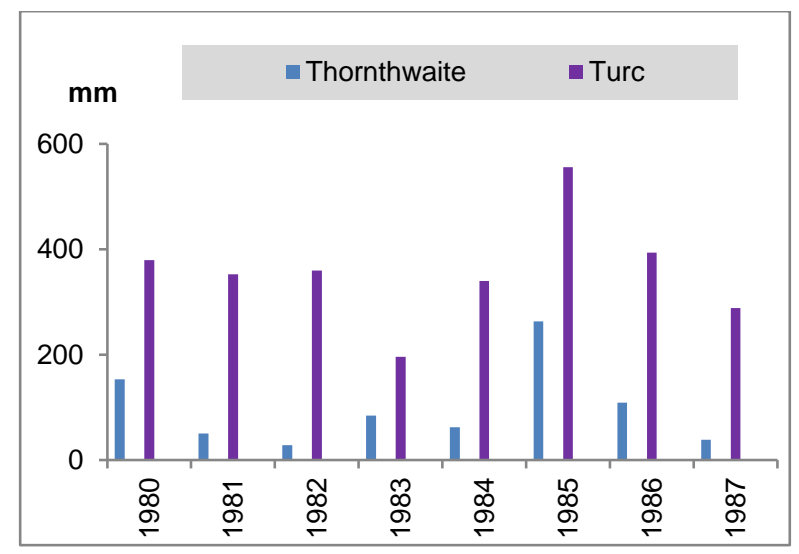

Fig. 4. Effective rain estimated under ESPERE modeling worksheet.
Recharge estimation through ESPERE modeling also considered evaporation with transpiration and river discharges, in addition of temperature and rainfalls entry data. Chronical filter methods such as Wallingford, Chapman and Eckart included in ESPERE package estimated aquifer annual recharge reached 2-173 $\mathrm{mm}$, while empirical methods (Turc and Thornthwaite) evaluated it $23-333 \mathrm{~mm}$. Figure 5 highlights precise values given by each method: Wallingford (2-173 mm), Chapman (4-103 mm), Eckhardt (5-124 mm), Turc (117-333 $\mathrm{mm})$ and Thornthwaite (23-158 mm).

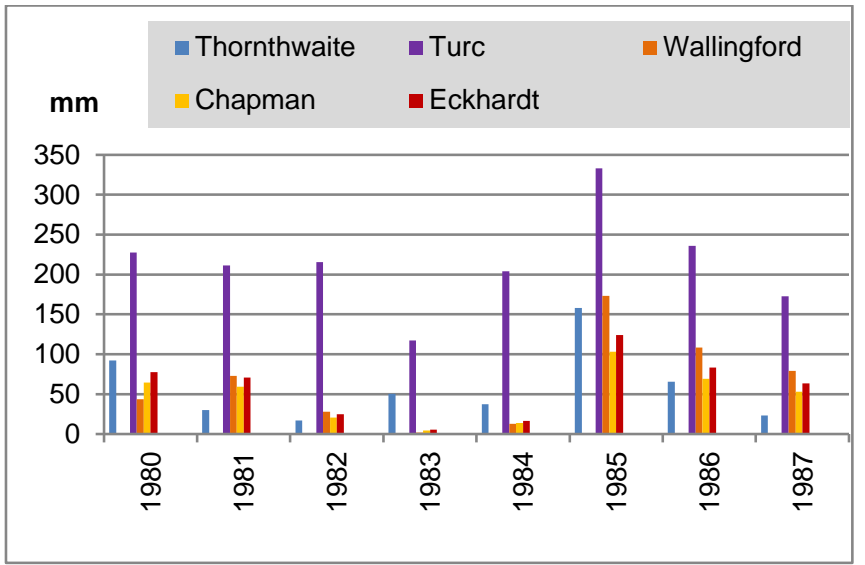

Fig. 5. Recharge estimated through different methods in ESPERE model.

This graphic revealed also that peak of groundwater storage occurred in year 1985 and the lowest storage intervened in year 1983. Comparatively to surface waters availability, aquifer recharge described similar evolution.

\section{Impact of climate variability on waters resources}

Relationship of rainfall and river discharges is well known through graph below (Fig. 6). It highlights a similar variation of runoff discharge and rainfall. River discharge closely followed rainfall evolution. Both climate parameters were affected by significant rupture occurred in year 1983-1984. Analysis of both downward values revealed that river discharge can be equals null while rainfall remain more than one unit. Surely, rain and river flow do not occur at the same instant date time.

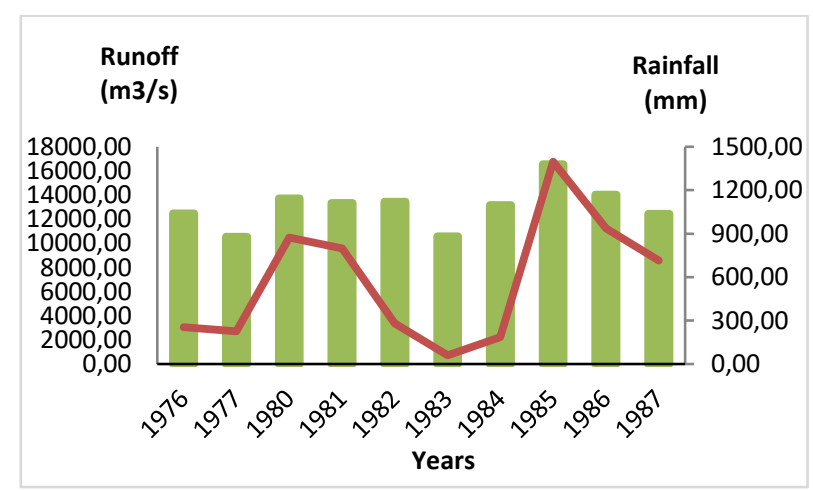

Fig. 6. Evolution of rainfall and runoff at Sinematiali.

Curves of river recession base flow evidenced duration of surface water flow at different years (Fig. 7 a, b, c, d, e, f). According these curves of recession, duration of river flowing can reach 10, 20 or 30 calendar days. This duration decreased progressively on period considered. 


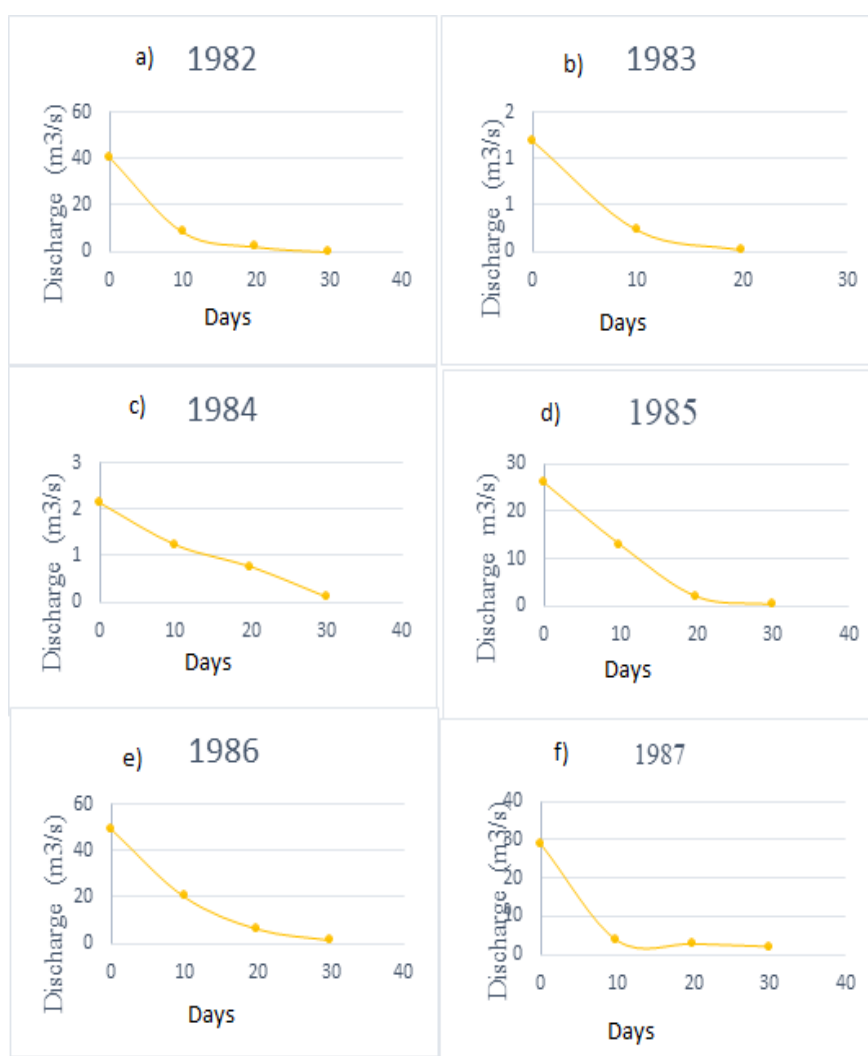

Fig. 7. Curves of flow recession of the Bandaman watershed at Sinématiali.

\section{DISCUSSION}

\section{A. Climate variability}

Previous works in the North region highlighted reality of rainfalls downward trend. According findings of [4] Korhogo region was characterized by humid period from 1950 to 1970 , a normal period from 1971 to 1975 and a deficit period from 1976 to 2000. Rainfall variability at Ferké including Sinematiali is not so different even if normal period was not identified, and dry with humid period occurred at similar period. Indeed, [9] explained that amplitude of the phenomenon is not uniform everywhere. Hydrological break about rivers discharges is one of parameter indicating climate change or variability. Otherwise, application of Pettit Test and Hubert segmentation by [3], showed that hydrological break occurred in 1980 and 1986 on whole Bandama watershed. Therefore, the year 1984 identified as a break period at Sinematiali is not in disagrement due to subwatershed scale consideration and other influencing factors such as effective spatial irregularity of rainfall suggested by [12-13].

\section{B. Quantitative recharge assessment}

Groundwater quantity mobilized by aquifers experienced a decrease following rainfalls and runoff discharges ones, from 1980 to 1983 . Therefore, the lasting depletion of runoff is linked to quantity of groundwater available in aquifers and structural relationship between surface and ground waters. Indeed, studied area was a witness of considerable depletion of underground reserve which normally ensure the supply of stream rivers during dry seasons. All method of estimation through ESPERE model described fluctuation of annual recharge and effective rain quantity mobilized.

They explained the strong extension of drought until year
1983 while annual recharge reached lowest value $(2 \mathrm{~mm})$ according Eckhardt method's finding and runoff recession duration reached 20 days. Such decrease of recharge value closely following runoff discharges is in accordance of previous works on Bandama catchment at Tortiya, localized at south of Sinematiali where recharge decreased -13,13\% according Thornthwaite method applied by [14]. Indeed, in addition of land use, decreasing of groundwater quantity in aquifers may partly explain modifications of rainfall-runoff relationship in most West or Central Africa large river catchments [15].

\section{Impact of climate variability on waters resources}

This study confirmed previous results about climate variability impacts on water resources. Significant impact is the reduction of time of water availability for users. At Sinematiali, time of river flow recession decreased progressively from 40 to 20 days, whereas river base flow recession was not up one week at N'zi - Bandaman subwatershed [16]. In the same view, [15-17] identified also similar evolution of rainfalls and runoff discharges. However, at Sinematiali, both phenomena did not begin at the same date time, and dry season was amplified into the flow's recession duration. Nethertheless, the rainfall deficit does not fully explain the decreasing trend of runoffs. Hydrological deficit should be attributed to the cumulative effect of long years of drought [15]. Therefore, rainfall variability could be affected groundwaters due its similar evolution with runoff and recharge. This finding can be explained by real connection of surface water and groundwaters in basement areas [18]. Otherwise, according their works about projections of impacts of climate change on water resources in the whole Bandama catchment, [5] revealed that increasing of greenhouse gases may significantly decrease aquifer recharge. Indeed,[19] indicated that climate changes were associated with large uncertainties in Sub-Saharan Africa.

\section{CONCLUSION}

This research helped for better understanding hydrological relationship occurred at sub-watershed scale of large River catchment. Main question on how water resource can be better managed for stakeholders in rural areas can get answers in the following relevant findings:

-A long humid climate period followed by a dry one based on rainfall index trend from.

-A reduction of days number of stream rivers recession flow, which decreased from 50 to 20 days

-An effective annual rainfall for infiltration and runoff estimated between $30-570 \mathrm{~mm}$

-Annual aquifer's recharge assessed between 2 and 333 $\mathrm{mm}$.

Based on these significant findings, waters resource of Bandama sub-watershed at Sinematiali can benefit better management in future days. That is why, this study opened modeling works such as using of coupled climate - surface water-groundwater models for helping decision makers and advising water users for wise and sustainable management of water resources at Sinematiali. 


\section{ACKNOWLEDGMENT}

The authors thank the Department of regional Office of National Agency for Rural Agricultural Development of Côte d'Ivoire Government for data acquisition.

\section{AUTHOR CONTRIBUTIONS}

Omer Zephir De Lasme developed and wrote the ideas; Avy Stephane Koffi and Gnali Dodo Cedric respectively contributed to the realization of the map and the data processing.

\section{CONFLICTS OF INTEREST}

The authors declare no conflict of interest.

\section{REFERENCES}

[1] W. M. Alley, T. E. Reilly, and and O. L Franke, "Sustainability of Groundwater Resources", Denver Colorado, U.S. Geological Survey circular 1186, p.20 Year 1999. doi: 10.3133.

[2] M. Valipour, "Necessity of irrigated and rainfed agriculture in the world"'. Irrigation and Drainage System Engineering. ISSN: 21689768 IDSE, an open access journal, S9-e001, 2013, DOI: $10.4172 / 2168-9768$.

[3] A.M.Kouassi, A.V.S Assoko; K. .Kouakou, K.B Dje, K.F, Kouame, J.Biemi. "Analyse des impacts hydrologiques de la variabilité climatique en Afrique de l'ouest: Cas du bassin versant du Bandama en Côte d'ivoire"' Larhyss Journal, no. 31, 2017.

[4] T. D Soro, 'Evolution des ressources en eau du bassin versant du Haut Bandama à Tortiya (Nord de la Côte d'Ivoire) dans un contexte de variabilité et de changement climatiques : impacts hydrologiques", $\mathrm{Ph} . D$. dissertation, Faculty of Earth Sciences and Mining Resources, University Félix Houphouët Boigny, Cocody-Abidjan, 250p., 2014.

[5] E. S. Gneneyougo Y. B. Affoué; M. K. Yao and T. A. Goula-Bi. "Climate Change and Its Impacts on Water Resources in the Bandama Basin, Côte D'ivoire”. Hydrology Journal, vol. 4, no.18; 2017,

[6] R. Bissour (www.geograchid.com).

[7] C. W. Thornthwaite, "An approach toward a rational classification of climate", Geography Revue., no.38, pp.55-94, 1948.

[8] S. Lanini, Y. Caballero, and P. Le Cointe - ESPERE, a multiplemethod Microsoft Excel application for estimating aquifer recharge Version 2 User's Guide. Translated from report BRGM/RP-69538-FR (in French).

[9] E Servat, JE Paturel, B Kouame, M Travaglio,' Water resources variability in Africa during the 20th century" / Variabilité des ressources en eau en Afrique au 20ème siècle "IAHS Publication, n 252, pp.323-337, 1998 ( In French)

[10] A.N. Pettit. "A non-parametric approach to the change - point problem." Applied Statistics, vol.28, no.2, pp.126-135, 1979.

[11] E. Maillet, 1905. Essais d'hydraulique souterraine et fluviale. HERMAN (Éditeur), Paris, 218 p. (In French)

[12] A. Hadour, G. Mahe, and M. Meddi. Study of the spatial and temporal variability of rainfall in the Middle and Lower Cheliff. Proceedings of IAHS publication, 383, 61-68, Beijing, September 2020. https://doi.org/10.5194/piahs-383-61-2020.

[13] J. E. Paturel, E. Servat, M. O. Delattre, Analyse de séries pluviométriques de longue durée en Afrique de l'Ouest et Centrale non sahélienne dans un contexte de variabilité climatique. Hydrological Sciences-Journal-des Sciences Hydrologiques, vol.43, no.6, pp.937946, December 1998.

[14] T. D Soro, B. D. Kouakou, E. A Kouassi, G Soro., A. M. Kouassi, , K. E. Kouadio, M.-S. O. Yéi, and N. Soro. Hydroclimatologie et dynamique de l'occupation du sol du bassin versant du Haut Bandama à Tortiya (Nord de la Côte d'Ivoire). VertigO, vol.13, no. 3, December 2013.

[15] G. Mahé, J.C Olivry., E. Servat. Sensibilité des cours d'eau ouest africains aux changements climatiques et environnementaux : extrêmes et paradoxes. IAHS Publication, n²96, pp.169-177, 2005.

[16] A.M. Kouassi, F.K. Kouamé, B.M. Saley, and J.Biémi."” Application du modèle de maillet a l'étude des impacts des changements climatiques sur les ressources en eau en Afrique de l'ouest : cas du bassin versant du n'zi-Bandama (Côte d'Ivoire)." Journal of Asian Scientific Research, vol. 3, no.2, pp 214-228, Year 2013.
[17] B.T.A Goula., I. Savane, B. Konan, V. Fadika, G.B Kouadio. ' Impact de la variabilité climatique sur les ressources hydriques des bassins de N'zo et N'zi en Côte d'Ivoire (Afrique tropicale humide)'. Vertigo, vol.7, n ${ }^{\circ}$, Mai 2006.

[18] O. Z. De Lasme. "Contribution à une meilleure connaissance des aquifères fissurés du socle Précambrien : cas de la région de San Pedro (Sud-ouest de la Côte d'Ivoire)". Ph.D. dissertation, Faculty of Earth Sciences and Mining Resources. University Félix Houphouët-Boigny, Cocody-Abidjan;176p, 2013. French

[19] O. Serdeczny, S.Adams, F. Baarsch, D. Coumou, A. Robinson, W. Hare, M. Schaeffer, M. Perrette, J. Reinhardt, 'Climate change impacts in Sub-Saharan Africa: From physical changes to their social repercussions". Regional Environmental Change, vol.17, pp. 15851600, 2016, doi : 10.1007/s10113-015-0910-2.

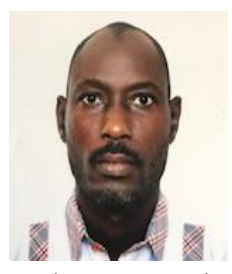

Omer Zephir De Lasme graduated Master and $\mathrm{PhD}$ respectively in 2008 and 2013 into earth sciences with specialization on groundwater hydrology at University Felix Houphouet-Boigny Abidjan-Cocody (Côte d'Ivoire). Since November 2013, he is enrolled as Assistant professor of earth sciences in the Geosciences Department at Faculty of Biological Sciences in the Peleforo Gon Coulibaly University, Korhogo, Cote d'Ivoire. In 2019, He graduated professional Master of Educational Technology at Laval University, Quebec, in Canada. His current research focuses on groundwater numerical flow modeling and integrated water management with hydrogeophysical inputs. in 2020, Dr O. Z. De Lasme is grantee of Fulbright Visiting Scholar at University of Hawaii at Manoa.

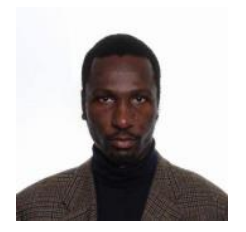

Avy Stephane Koffi graduated Master and $\mathrm{PhD}$ respectively in 2008 and 2014 at Faculty of Sciences of ibn Tofail University at Kenitra in Morocco. His graduated dissertations focused on natural risks managment by using remote sensing and GIS tools. Since end of 2014, he holds Assistant LecturerResearcher position at Geosciences Department of Biological Sciences Faculty of Peleforo Gon Coulibaly University of Korhogo. in the North of Côte d'Ivoire. In 2018, He graduated professional Master of educational technology sciences at Laval University, Quebec in Canada. Dr A.S. KOFFI is a geomatic specialist whose current research focuses on geomorphology, hydrology, numerical modeling of water related agroecosystem and remote sensing with drones.

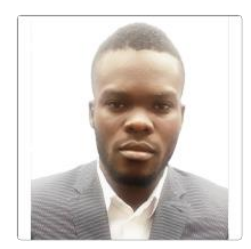

Dodo Cedric Gnali graduated bachelor of biological science in 2018, and Master of natural resources management in May 2020 at Faculty of Biological Sciences of University Peleforo Gon Coulibaly -Korhogo in Côte d'Ivoire. He latest research focused on climate variability and hydrological characterization of watershed. Mr D.G.C.Gnali is a potential candidate of $\mathrm{PhD}$ studies focused on sustainable natural resources management by using GIS and numerical modeling of water related agroecosystems. 